\title{
Climatic Changes and Psychiatric Disorders
}

\author{
iklimsel Değişiklikler ve Psikiyatrik Hastalıklar
}

\author{
Kader Semra Karatas ${ }^{1^{\star}}$, Sevda Ocak ${ }^{2}$ \\ ${ }^{1}$ Recep Tayyip Erdogan University, Psychiatry Department, Rize, Turkey \\ ${ }^{2}$ Giresun University, Engineering Faculty, Environmental Enginery, Giresun, Turkey
}

\begin{abstract}
Although recognition of seasonal influences on psychiatric disorders lie down old times, documentation of seasonal influences is not more than two decades old. The imbalance of meteorological factors, such as mean temperature, day light duration, humidity, atmospheric pressure can create many disorders in the normal life of sensitive people. The most common reaction to changing weather conditions could have seen as a psychological, emotional or behavioral character and seen as many psychiatric disorders or increases incidence of the psychiatric diseases. While many studies have focused on the impact of seasonality at bipolar and related disorders there have a little knowledge about other psychiatric disorders such as schizophrenia, sleep disorders, anxiety disorders. Same brain regions, neuronal phasic firing, neuronal transmission, presynaptic / postsynaptic neurotransmitter's level changes can be affected similar way by climatic changes, psychological status, psychiatric diseases. Several researchers have studied different affect of climatic factors to susceptible people and/or people who have psychiatric diseases, but seasonality is still unclear in those population. In this literature we have reviewed association among meteorological factors, like temperature, day light duration, humidity, atmospheric pressure, psychological states and psychiatric disorders by searching Medline, PubMed, Science direct literature scanning.
\end{abstract}

Keywords: climatic changes, sleep disorders, bipolar disorders, suicides, anxiety disorders

\section{Introduction}

\section{Sleep / Sleep Disorders}

Human sleep is susceptible to environmental changes. Normal human sleep is formed with nonrapid eye movement (NREM) sleep and rapid eye movement (REM) sleep. Sleep begins in NREM that have content light sleep stage and deep sleep stages in which slow wave sleep (SWS) have. REM sleep occurs approximately 1.5 hours later from NREM sleep, after which it reoccurs every 1.5-2 hours in different episodes (1-3). Subjective measures of sleep with climatic changes generally

\section{ÖZET}

Mevsimsel değişikliklerin psikiyatrik hastalıklar üzerine etkisi eski çağlara kadar uzansa da mevsimsel etkilerinin kayıt altına alınması iki dekad önceyi geçmemektedir. Ortalama 1sı, gün 1şığı süresi, nem, atmosferik basınç gibi meteorolojik faktörlerdeki dengesiz durum normal hayatta birçok duyarlı insanda çeşitli hastalıklar oluşturabilir. Değişen hava durumlarına en çok psikolojik, duygusal ya da davranışsal tepkiler verilebilir ve duyarlı kişilerde psikiyatrik birçok hastalıklarla karşımıza çıabilir ya da olan hastalıkların insidansını arttırabilir. Çalışmaların çoğunluğu mevsimselliğin iki uçlu ve ilişkili bozukluklar üzerine etkisini araştırırken şizofreni, uyku bozuklukları, anksiyete bozuklukları, intihar davranışı gibi psikiyatrik hastalıklara etkisi hakkında çok az bilgi vardır. İklimsel değişiklikler, psikolojik durumlar, psikiyatrik hastalıklar aynı beyin bölgeleri, nöronal fazik ateşleme, nöral transmisyon, presinaptik /post sinaptik nörotransmitter düzeyinde değişiklikler şeklinde etkilerle benzer yollakları etkileyebilir. Birçok araştırmacı iklimsel değişikliklerin duyarlı kişilerde ve /veya psikiyatrik hastalığı olan kişilerde etkisini çalışmışsa da bu populasyonlarda mevsimselliğin etkisi halen belirgin değildir. Biz bu derlemede Medline, PubMed, Science direct makalelerini tarayarak 1s1, gün 1şığı, nem, atmasferik basınç gibi meteorolojik faktörler, psikolojik durum ve psikiyatrik hastalıklar arasındaki ilişkiyi gözden geçirdik.

Anaktar Kelimeler: iklimsel değişiklikler, uyku bozukluklar1, bipolar bozukluklar, suisidler, anksiyete bozuklukları

studied by sleep quality questionnaires (4). Recently researches evaluate sleep with polysomnography which is objective measures of sleep that appraise human sleep at different environmental situation $(3,4)$.

Temperature is a kind of environmental factor that sleep studies have done in different temperature to see the possible affect on human sleep (3). Core body temperature is a physiological phenomenon that cause changes to heat with increases or decreases alteration. It was shown that decreasing of core body temperature causes sleep initiation and may be helpful to entry into 
the deeper stages of sleep (4). Recent studies have shown that there is an association between core (rectal) temperature and distal (foot) temperature to regulate sleep. Core temperature decreases in older ages which affects to circadian rhythms and causes poor sleep quality. A warm bath before sleeping can reduce foot temperature and improve sleep in young women $(5,6)$. The thermoregulatory and sleep regulatory systems are not understood well but they can be associated with each other. Many studies show that the preoptic area/anteriorhypothalamus, which is the major brain region drives heat loss, is important for sleep regulation (5). When the heat reduces on distal part of body, it affects both circadian rhythm of body temperature and the sleep-wake cycle that causes sleep. The pathophysiology of sleepiness is due to enlarged blood vessels which lies at distal part of the body (5-8). The effect of the heat is measured with subjective measurement on susceptible persons. These results are supported with objective measurement like PSG. There had been no significant changes between PSG and subjective measurement $(3,5)$. However, some researchers have showed reduced sleep latency, increased SWS and elevated sleep quality in short-term heat exposure with laboratory studies (3,6-8). The other researches have shown decreases both in SWS and REM sleep or solely REM sleep with frequent sleep interruptions when the sleep continue between 31 and $38{ }^{\circ} \mathrm{C}$ (4). Midnight hypothermia caused numerous awakenings and sleep disruption. REM sleep episodes were much shorter in the cold (3). The effects of heat or cold exposure are increased wakefulness and decreased REM sleep and SWS (8). Thermal environment's impact on sleep stages regulating sleep mechanism are closely associated with thermoregulation $(3,6)$. Thus, environment (like suitable temperature) is important for sleep maintenance (8). Light is another factor that is affecting human sleep. Melatonin is secreted from pineal gland and regulates sleep cycles. Sun light is effective on melatonin secretion. Melatonin is associated with sleep latancy and sleep quality because of its hypothermic effect. At night time melatonin levels increases, core temperature decreases and sleep sensation is elevated. Exhaustive studies have shown that melatonin can make sleep quality better $(3,9)$. Sleeping under warm humid conditions did not cause any apparent changes both in hot and dry climate. $(3,10)$. Altitude is an agent that can effect human sleep. Insomnia appear at altitudes over $2000 \mathrm{~m}$. Sleep parameters especially SWS is a decreased with several arousal reactions. Obstructive sleep apnea can be worsened, and central sleep apnea can be seen in high altitudes. The pathophysiology of sleep disturbance is considered related with oxygen desaturation and respiratory disturbances (11).

When the sleep wakefulness cycle such as sleep latency, NREM sleep stages, REM latency, REM sleep effected it can be seen as insomnia, hypersomnia, parasomnia, circadian rhythm disturbance at sensitive persons.

\section{Mood/ Bipolar and Related Disorders}

Mood is a sensation that is associated with multi variable environmental factor (12). Several studies have shown that atmospheric conditions can affect well-being or disease, at some individuals (12-16). An association between season and depression is demonstrated (17). Bipolar disorders (BD) is a mood disorder that is seen with periods of hypomanic/manic and depressive episodes. It has found that climatic variables such as hours of sunshine, temperature and rainfall have a significant association with the admission rates for manic, depressive episodes (18-20). Researches have shown that manic episode is mostly seen in spring. It can be associated with hours of sunshine and sunlight radiation (20). The spring or summer peak in mania has not been a universal finding, as some investigators report bimodal peaks in spring (21). Moreover, other studies cannot demonstrate any seasonal variation in referral rates for mania $(1,18,22)$. It was shown that when the temperature is rising at summer $\mathrm{BD}$ patients hospital admission rate is increasing (23). Although admission rates are high between spring/summer time and manic episodes, there have less sign on seasonal influences in depressive episodes $(2,3,19,24)$. There are few studies about mixed episodes admission and seasonality. It is considered that late summer peak has been more in mixt episodes $(2,24,25)$. Seasonality of BD mixed episode has been studied at eastern Turkey at Blacksea in Rize and found that winter admissions were most in mixt episodes (26). Seasonal affective disorders (SAD) is a subtype of $\mathrm{BD}$ which is worsened in winter and been well at spring/summer time (3). It is considered that sunlight radiation and neurochemical changes are associated with SAD (23). Guzman et al. 2007 hypothesized that polen, aeroallergen can cause inflammation in the respiratory airways that will be associated with depression in vulnerable individuals as called non-winter SAD (27). Lee et al. (2012) has reported that SAD is associated with delayed sleep phase syndrome (21). SAD patients 
become depressed in the winter at least in part because of a phase delay with respect to the sleep/wake cycle. Sky cover can change in photoperiod and light intensity. It is related with circadian rhythmicity in humans and can associate with the pathophysiology of BD $(28,29)$. The circadian rhythm of temperature is endogenous. The depressive phase of patients may have temperature-clock desynchronization. Sufferers from depressive illness especially worsen at the morning time that can be closely related with body temperature $(30,31)$. Small positive ions which is high concentration on the atmosphere is related to atmospheric humidity that is associated with psychiatric symptoms such as mania. A negative correlation between manic admissions and relative humidity was observed $(5,27,28)$.

\section{Schizophrenia}

While many studies of seasonal variation in psychiatric admissions focus on the affective disorders, some authors have reported seasonal variation in schizophrenia (33-38). There have been varied data about temperature and schizophrenia. Although some studies have supported that temperature is a factor which caused admission rates of schizophrenia (32-34) but other studies have not supported it $(35,37)$. Byrne et al. (2015) have reported the summer peak in admissions for schizophrenia (38). Zhao et al. have found that increasing temperature was especially associated with an increased risk for schizophrenia admissions. Moreover, the associations of temperature with schizophrenia admissions is linked with gender (34). Some studies have found a summer peak for schizophrenia only in females (36-38). There are few studies and knowledge about the impact of temperature on schizophrenia.

Researchers have studied relation between birth season and schizophrenia (39-44). Schizophrenia was seen more in winter births that is support with the viral hypothesis of schizophrenia (41). However, Wang and Zhang (2017) have reported that people who were borned in spring have highest risk for schizophrenia (42). Reid and Zbrowski (2006) have found that schizophrenics have been reported to show increasing rates in cold weather like winter and spring births. They have also reported latitude plays a role plays in the seasonality impact of schizophrenia (43). Suvisaari et al. have investigated schizophrenia, siblings, environmental seasonal factors, winter- spring birth, that have found no relation with each of them (44). Schawartz (2014) has reported that melatonin levels decreased at second trimester of pregnancy in winter and that was affecting core temperature and increased excitability of hippocampal, ventral striatal dysfunction. Author also considered that winter melatonin levels can be associated with propensity for abnormal nigrostriatal neuronal phasic firing and increased presynaptic nigrostriatal dopamine transmission as called maternal-fetal chronobiological hypothesis (39). Hypothalamic suprachiasmatic nucleus is regulated by photoperiod and that affects dopamine signaling and neurotransmission. In many studies infections, latitude, season, temperature have been discussed but there no absolute results stating an association with schizophrenia and them (44).

\section{Suicides}

Increasing suicides are major public health problem of the world. Although epidemiological studies for suicides have proposed numerous factors by several researches, seasonal impact has drawn remarkable attention recent history $(45,46)$. Many studies have consistently demonstrated seasonal fluctuations in suicidal deaths in several populations (45-51). There is widely belief that darkness is a major factor of suicides and winter and autumn is a risk factor for suicides. But most of the studies showing spring and summer peaks (45). Björksten et al. (2009) have been studied that a suicide was mostly in the summer months (47) and most reported at high latitudes (46). Violent suicides such as falling from high, shooting deaths, hanging etc. are more common in summer $(48,49)$ and the majority of suicides seem impulsive. Some researchers have suggested that biochemical mediators have major role to differentiate of suicide types and heterogeneity. Authors have also reported that plasma levels of serotonin and melatonin concentrations are changed with seasonal suicides (48). Some authors have hypothesized that not heat but lack of cold were associated with suicides (45). The researches have shown that there was a relationship between sunlight, temperature and suicide $(46,50,51)$. Some authors have reported that suicides were associated with elevated temperature, sunlight duration and humidity (48). There have been no consistent results shown with the other meteorological data like precipitation (45).

\section{Anxiety / Anxiety Disorders}

Seasonality is still unclear in anxiety or anxiety disorder in healthy group and patients with any anxiety disorder. Winthorst et al. (2011) have searched the seasonal affect on anxiety disorders and healty group. They have found no association 
between seasonality and healty group. Also they have found minimal increase of depressive symptoms with seasonality at anxiety disorders. Severity of anxiety symptoms were lowest at autumn and spring, highest at winter and summer (52). Many researchers studied the affect of season with questionnaire studies at anxiety and/or anxiety disorders. They are suggested that there is different reaction in several months (52-54). Although researchers have found a peak of prevalence for anxiety disorders in any month (55), general anxiety disorder, panic disorder, obsessive-compulsive disorder (OCD), tensionanxiety are reported to be most prevalent in autumn and winter months $(54,56)$. It is known that both OCD are associated with high levels of anxiety. Tan et al. (2016) have showed the duration of sunlight is associated with compulsions but not obsessions in OCD. They have also shown the affect of seasonality and sunlight exposure to OCD are far from being explained by our current knowledge (57). The psychobiological basis underlying relation between seasonality and anxiety/anxiety disorders are still uncertain $(53,57)$.

As a result of bioclimatic variation and seasonal changes may affetct many sensitive persons and causes several psychological states and psychiatric disorders. Although many studies have shown that possible affects of climatic changes on brain regions, neuronal phasic firing, presynaptic and postsynaptic neurotransmission but there are not enough studies to evaluate these situations and more studies are needed.

\section{References}

1. M.A. Carskadon, W.C. Dement. Normal human sleep: an overview. M.H. Kryger, T. Roth, W.C. Dement, editors. Principles and Practice of Sleep Medicine. 5th ed. Elsevier Inc., Philadelphia 2011. pp. 16-26.

2. Karatas KS. Dissosiyatif Bozuklugu olan ve olmayan Parasomni hastalarının karşılaştırılması. Postgraduate thesis. Erenkoy Research and Training Hospital for Mental and Nervous Diseases, Istanbul 2012.

3. Buguet A. Sleep under extreme environments: Effects of heat and cold exposure, altitude, hyperbaric pressure and microgravity in space. Journal of the Neurological Sciences 2007; 262(12): 145-152.

4. Lan L, Tsuzuki K, Liu YF, Lian ZW. Thermal environment and sleep quality: A reviewL Energy and Buildings 2017; 149: 101-113.

5. Liao WC, Wang L, Kuo CP, Lo C, Chiu MJ, Ting $\mathrm{H}$. Effect of a warm footbath before bedtime on body temperature and sleep in older adults with good and poor sleep: An experimental crossover trial. International Journal of Nursing Studies 2013; 50(12): 1607-1616.

6. Van Someren E.J.W. More than a marker: interaction between circadian regulation of temperature and sleep age-related changes, and treatment possibilities. Chronobiol 2000; 17(3): 313-354.

7. van Maanen A, Roest B, Moen M, Oort F, Vergouwen P, Paul I, et al. Extreme Violation of Sleep Hygiene: Sleeping Against the Biological Clock During a Multiday Relay Event. Asian J Sports Med 2015; 6(4): e25678.

8. Okomoto-Mizuno K, Mizuno K. Effects of thermal environment on sleep and circadian rhythm. JSPA 2012; 14: 31-34.

9. Ozcelik F, Erdem M, Bolu A, Gulsun M. Melatonin: General Features and its Role in Psychiatric Disorders. Current Approaches in Psychiatry 2013; 5(2): 179-203.

10. Alain Buguet A, Bogui P, Picot S, Cespuglio R. Sleep patterns in villagers and urban African volunteers in a humid tropical climate: Influence of accessibility to electric light? Journal of the Neurological Sciences 2017; 376: 44-48.

11. Zielinski J, Koziej M, Makowski M, Sarybaev AS, Tursalieva JS, Sabirov IS, et al. The quality of sleep and periodic breathing in healthy subjects at an altitude of $3200 \mathrm{~m}$. High Alt Med Biol 2000; 1(4): 331-336.

12. Geoffroy PA, Bellivier F, Scott J, Etain B. Seasonality and bipolar disorder: a systematic review, from admission rates to seasonality of symptoms. J Affect Disord. 2014; 168: 210-223.

13. Cassidiy F, Carroll BJ. Seasonal variation of mixed and pure episodes of bipolar disorder. J. Affect. Disord 2002; 68(1): 25-31.

14. Elbi H, Noyan A, Korukoğlu S, Unal S, Bekaroglu $\mathrm{M}$, Oguzhanoglu N, Seasonal affective disorder in eight groups in Turkey: a cross-national perspective. Affect Disord 2002; 70(1): 77-84.

15. Yackerson NS, Zilberman A, Todder D, Kaplan $Z$. The influence of several changes in atmospheric states over semi-arid areas on the incidence of mental health disorders. Int J Biometeorol 2011; 55(3): 403-410.

16. Salib E, Sharp N. Relative humidity and affective disorders. Int J Psychiatry Clin Pract 2002; 6(3): 147-153.

17. Oyane NM, Bjelland I, Pallesen S, Holsten F, Bjorvatn B. Seasonality is associated with anxiety and depression: the Hordaland health studv. I Affect Disord 2008; 10

18. Bauer M, Glenn T, G W, Sagduyu K, et al. Relationship among latitude, climate, season and self-reported mood in bipolar disorder. J Affect Disord 2009; 116(1-2): 152-157.

19. Morken G, Lilleeng S, Linaker O.M. Seasonal variation in suicides and in admissions to hospital 
for mania and depression. J. Affect. Disord 2002; 69(1-3): 39-45.

20. Lee HJ, Kima L, Joea SH, Suh KY. Effects of season and climate on the first manic episode of bipolar affective disorder in Korea. Psychiatry Research 2002; 113(1-2): 151-159.

21. Lee HJ, Rex KM, Nievergelt CM, Kelsoe JR, Kripke DF. Delayed sleep phase syndrome is related to seasonal affective disorder. J Affect Disord 2011; 133(3): 573-579.

22. Volpe FM, Del Porto JA. Seasonality of admissions for mania in a psychiatric hospital of Belo Horizonte, Brazil. J Affect Disord 2006; 94(1-3): 243-248.

23. Magnusson A. An overview of epidemiological studies on seasonal affective disorder. Acta Psychiatr Scand 2000; 101(3): 176-184.

24. Cassidy F, Ahearn E.P, Murry E, Forest K, Carroll B.J. Diagnostic depressive symptoms of the mixed bipolar episode. Psychol. Med 2000; 30(2): 403-412.

25. Boker SM, Leibenluft E, Deboeck PR, Virk G, Postolache TT. Mood Oscillations and Coupling Between Mood and Weather in Patients with Rapid Cycling Bipolar Disorder. Int J Child Health Hum Dev 2008; 1(2): 181-203.

26. Karatas KS et al. Bipolar Disorder and Seasonal Change. International Environmental Science Symposium of Van, Turkey 2014.

27. Guzman A, Tonelli LH, Roberts D, Stiller JW, Jackson MA, Soriano JJ, et al. Mood-worsening with high-pollen-counts and seasonality: a preliminary report. J Affect Disord 2007; 101(13): 269-274.

28. Lee HC, Tsai SY, Lin HC. Seasonal variations in bipolar disorder admissions and the association with climate: a population-based study. J Affect Disord 2007; 97(1-3): 61-69.

29. Goodwin GM, Malhi GS. What is a mood stabilizer? Psychol Med 2007; 37(5): 609-614.

30. Moon JH, Cho CH, Son GH, Geum D, Chung S, Kim H, et al. Advanced Circadian Phase in Mania and Delayed Circadian Phase in Mixed Mania and Depression Returned to Normal after Treatment of Bipolar Disorder. EBioMedicine 2016; 11: 285 295.

31. Partonen T. Mood Episode Recovery Changes Gear in the Intrinsic Clock. EBioMedicine 2016; 11: 25-26.

32. Wang X, Lavigne E, Ouellette-kuntz H, Chen BE. Acute impacts of extreme temperature exposure on emergency room admissions related to mental and behavior disorders in Toronto, Canada. J Affect Disord 2014; 155: 154-161.

33. Gupta S, Murray RM. The relationship of environmental temperature to the incidence and outcome of schizophrenia. Br. J. Psychiatry 1992; 160: 788-792.
34. Zhao D, Zhang X, Xie M, Cheng J, Zhang H, Wang $S$, et al. Is greater temperature change within a day associated with increased emergency admissions for schizophrenia? Science of The Total Environment 2016; (566567): 1545-1551.

35. Sung TI, Chen MJ, Lin CY, Lung SC, Su HJ. Relationship between mean daily ambient temperature range and hospital admissions for schizophrenia: results from a national cohort of psychiatric inpatients. Sci. Total Environ 2011; (410-411): 41-46.

36. Clarke M, Moran P, Keogh F, Morris M, Kinsella $A$, Walsh D, et al. Seasonal influences on admissions in schizophrenia and affective disorder in Ireland. Schizophr Res 1998; 34(3): 143-149.

37. Daniels BA, Kirkby KC, Mitchell P, Hay D, Mowry B. Seasonal variation in hospital admission for bipolar disorder, depression and schizophrenia in Tasmania. Acta Psychiatr Scand 2000; 102: 38-43.

38. Byrne EM, Raheja UK, Stephens SH, Heath AC, Madden PA et al. Seasonality shows evidence for polygenic architecture and genetic correlation with schizophrenia and bipolar disorder. J Clin Psychiatry. 2015; 76(2): 128-134.

39. Schwartz PJ. Can the season of birth risk factor for schizophrenia be prevented by bright light treatment for the second trimester mother around the winter solstice? Medical Hypotheses 2014; 83(6): 809-815.

40. Praschak-Rieder N,Willeit M. Imaging of Seasonal Affective Disorder and Seasonality Effects on Serotonin and Dopamine Function in the Human Brain. Curr Topics Behav Neurosci 2012; 11: 149-167.

41. Altamura AC, Bassetti R, Bocchio L, Santini A, Mundo E. Season of birth and inflammatory response system in schizophrenia Progress in Neuro-Psychopharmacology \& Biological Psychiatry 2003; 27(5): 879-880.

42. Wang C, Yudong Zhang Y. Season of birth and schizophrenia: Evidence from China. Psychiatry Research 2017; 253: 189-196.

43. Reid HM, Zborowsk MJ. Schizophreniaproneness, season of birth and sleep: Elevated schizotypy scores are associated with spring births and extremes of sleep. Personality and Individual Differences 2006; 41: 1185-1193.

44. Suvisaari JM, Haukka JK, Lönnqvist JK. Season of birth among patients with schizophrenia and their siblings; evidence for the procreational habits hypothesis. Am J Psychiatry 2001; 158(5): 519-525.

45. Ajdacic-Gross V, Lauber C, Sansossio R, Bopp M, Eich D, Gostynski M. Seasonal Associations between Weather Conditions and SuicideEvidence against a Classic Hypothesis. Am J Epidemiol 2007; 165(5): 561-569. 


\section{Karatas ve Ocak /İklim ve Psikiyatrik Hastalıklar}

46. Björksten KS, Kripke DF, Bjerregaard P. Accentuation of suicides but not homicides with rising latitudes of Greenland in the sunny months. BMC Psychiatry 2009, 9:20. https://doi.org/10.1186/1471-244X-9-20.

47. Bjorksten KS, Bjerregaard P, Kripke DF: Suicides in the midnight sun - a study of seasonality in suicides in West Greenland. Psychiatry Res 2005, 133(2-3): 205-213.

48. Lin HC, Chen CS, Xirasagar S, Lee HC. Seasonality and Climatic Associations with Violent and Nonviolent Suicide: A PopulationBased Study. Neuropsychobiology 2008; 57:3237.

49. Kalediene R, Starkuviene S, Petrauskiene J: Seasonal patterns of suicides over the period of socio-economic transition in. Lithuania. BMC Public Health 2006; 6: 40.

50. Lambert G, Reid C, Kaye D, Jennings G, Esler $\mathrm{M}$ : Increased suicide rate in the middle-aged and its association with hours of sunlight. Am J Psychiatry 2003; 160(4): 793-795.

51. Petridou E, Papadopoulos FC, Frangakis CE, Skalkidou A, Trichopoulos D: A role of sunshine in the triggering of suicide. Epidemiology 2002; 13(1): 106-109.

52. Winthorst WH, Post WJ, Meesters Y, Penninx BW, Nolen WA. Seasonality in depressive and anxiety symptoms among primary care patients and in patients with depressive and anxiety disorders; results from the Netherlands Study of Depression and Anxiety. BMC Psychiatry. 2011; 11: 198. https://doi.org/10.1186/1471-244X-11198.

53. Oyane NMF, Bjelland I, Pallesen S, Holsten F, Bjorvatn B. Seasonality is associated with anxiety and depression: the Hordaland health study. J Affect Disord. 2008; 105(1-3): 147-55.

54. de Graaf R, van Dorsselaer S, ten Have M, Schoemaker C, Vollebergh WA. Seasonal variations in mental disorders in the general population of a country with a maritime climate: findings from the Netherlands mental health survey and incidence study. American Journal of Epidemiology 2005; 162(7): 654-661.

55. Posternak MA., Zimmerman M. Lack of association between seasonality and psychopathology in psychiatric outpatients. Psychiatry Research 2002; 112: 187-194.

56. Harmatz MG, Well AD, Overtree CE, Kawamura KY, Rosal M, Ockene IS. Seasonal variation of depression and other moods: a longitudinal approach. Journal of Biological Rhythms 2000; 15(4): 344-350.

57. Tan O, Metin B, Unsalver BO, Hizli Sayar G. Seasonal mood changes in patients with obsessive-compulsive disorder. Psychiatry Research (2016), http://dx.doi.org/10.1016/j.psychres.2016.04.088 . Article in Press. 